\title{
DEVELOPMENT AND VALIDATION OF UV SPECTROSCOPIC METHOD FOR ESTIMATION OF LAMIVUDINE IN TABLET DOSAGE FORM
}

\author{
KALPESH V. SONAR ${ }^{a *}$, PRABODH SAPKALEa, ANIL JADHAVb, TUSHAR DESHMUKHª, SWAPNIL PATIL ${ }^{a}$, PALLAVI \\ MURKUTE ${ }^{a}$
}

aDepartment of Pharmaceutical Chemistry, Arunamai College of Pharmacy, North Maharashtra University, Mamurabad, Jalgaon (MH), India 425001, bDepartment of Pharmaceutical Chemistry, Sandip Institute of Pharmaceutical Sciences, Pune University, Nasik (MH) India 422231 Email: kalpesh.sonar@gmail.com

Received: 23 Aug 2017, Revised and Accepted: 13 Oct 2017

\section{ABSTRACT}

Objective: To develop and validate simple, rapid, linear, accurate, precise and economical UV Spectroscopic method for estimation of Lamivudine in tablet dosage form.

Methods: The drug is freely soluble in analytical grade water. The drug was identified in terms of solubility studies and on the basis of melting point done on melting point apparatus of Equiptronics. It showed absorption maxima were determined in analytical grade water. The drug obeyed the Beer's law and showed a good correlation of concentration with absorption which reflects in linearity. The UV spectroscopic method was developed for estimation of lamivudine in tablet dosage form and also validated as per ICH guidelines.

Results: The drug is freely soluble in analytical grade water, slightly soluble in methanol and practically insoluble in acetone. So, the analytical grade water is used as a diluent in the method. The melting point of lamivudine was found to be $160-161^{\circ} \mathrm{C}$ (uncorrected). It showed absorption maxima $268 \mathrm{~nm}$ in analytical grade water. On the basis of the absorption spectrum, the working concentration was set on $10 \mu \mathrm{g} / \mathrm{ml}(\mathrm{PPM})$. The linearity was observed between $6-14 \mu \mathrm{g} / \mathrm{ml}$ (PPM). The results of the analysis were validated by recovery studies. The recovery was found to be 98.7, 101 and $99.2 \%$ for three levels respectively. The $\%$ RSD for precision was found to be $0.62 \%$.

Conclusion: A simple, rapid, linear, accurate, precise and economical UV Spectroscopic method has been developed for estimation of Lamivudine in tablet dosage form. The method could be considered for the determination of Lamivudine in quality control laboratories.

Keywords: Lamivudine, UV Spectrophotometer, Melting Point, Assay Method, Validation, Accuracy, Linearity, Ruggedness, Precision

(C) 2017 The Authors. Published by Innovare Academic Sciences Pvt Ltd. This is an open access article under the CC BY license (http://creativecommons.org/licenses/by/4.0/] DOI: http://dx.doi.org/10.22159/ijcpr.2017v9i6.23658

\section{INTRODUCTION}

Lamivudine (3TC; 2, 3-dideoxy-3-thiacytidine) (-) enantiomer of a dideoxy analogue of cytidine can inhibit both types of HIV reverse transcriptase and also the reverse transcriptase of hepatitis B virus [1-2]. It is phosphorylated intracellular 1to it's active 5'thiophosphate metabolite, lamivudine thiophosphate (L-TP) [3-4]. This nucleoside analogue is incorporated into viral DNA by HIV reverse transcriptase and HBV polymerase, resulting in DNA chain termination [5]. Lamivudine is taken by mouth as liquid or tablet. Lamivudine has very low cytotoxicity. It is rapidly absorbed with a bioavailability of approximately $80 \%$ [6]. It is used in combination with other antiretroviral such as ziovudine and abacavir [7].

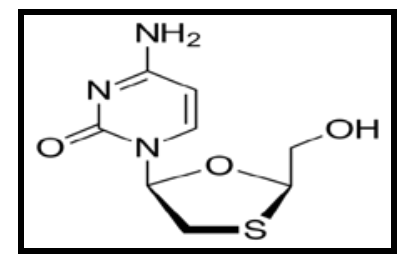

Fig. 1: Chemical structure of lamivudine

Literature review reveals that lamivudine inhibits hepatitis B virus replication, as well as the lamivudine treatment, is beneficial in patients with severely decompensated cirrhosis and actively replicating hepatitis B infection awaiting liver transplantation.

From the literature review, it's found that one method was reported on derivative spectrophotometry for simultaneous estimation of lamivudine their combined dosage form. Also, the method was reported on human serum and drug dissolution studies of lamivudine with another drug on HPLC $[8,9]$. Lot of work was done on UV method development for lamivudine in combination with other drugs [10-13]. But very few methods were reported on the estimation of lamivudine in tablet dosage form for UV spectroscopic method. This indicates that so far no UV method exists for the estimation and determination of Lamivudine in tablet dosage forms. The aim of the study was to develop a simple, precise, linear, economic and accurate UV method for determination of Lamivudine in tablet dosage forms [14].

\section{MATERIALS AND METHODS}

\section{- Instruments}

Shimadzu double beam UV-visible spectrophotometer 1700 Ultra with matched pair

Quartz cells corresponding to $1 \mathrm{~cm}$ path length and spectral bandwidth of $1 \mathrm{~nm}$, Bath sonicator and citizen weighing balance.

Melting point apparatus of Equiptronics were used.

\section{- Materials}

Lamivudine was obtained as a gift sample. Lamivudine tablets were procured from a local pharmacy. Water used was of analytical grade. Glass double distilled analytical grade water was used throughout the experiment. Freshly prepared solutions were employed.

\section{Method development}

Determination of $\lambda$ max (15 PPM)

$100 \mathrm{mg}$ weighed the amount of lamivudine was dissolved into 100 $\mathrm{ml}$ of the volumetric flask with analytical grade water. Pipette out 
$1.5 \mathrm{ml}$ and added in $100 \mathrm{ml}$ of volumetric flask dissolved and diluted up to the mark with analytical grade water. This solution was subjected to scanning between 200-400 $\mathrm{nm}$ and absorption maximum was determined [15-16].

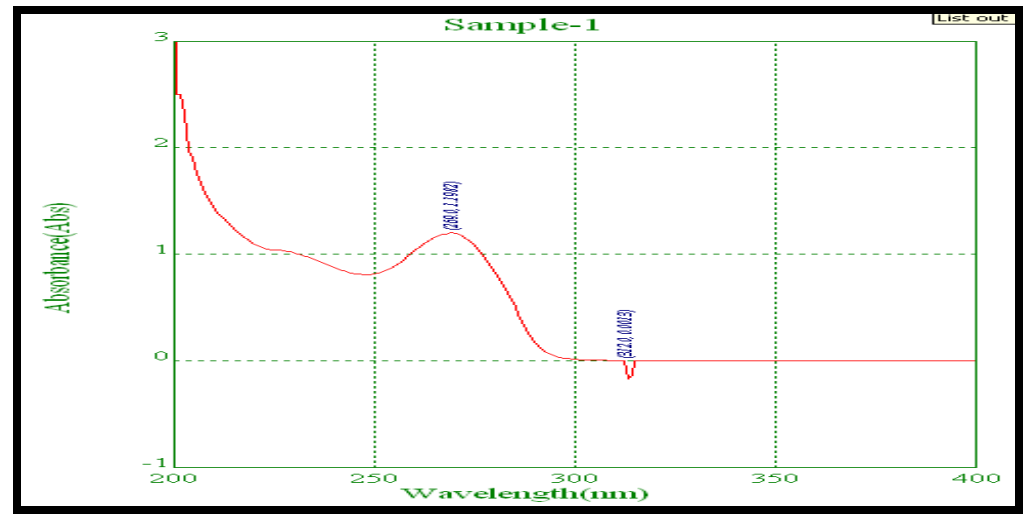

Fig. 2: Calibration curve

\section{A. Preparation of working concentration}

\section{Preparation of standard stock solution}

Standard stock was prepared by dissolving $100 \mathrm{mg}$ of lamivudine in 100 $\mathrm{ml}$ of analytical grade water to get a concentration of $1000 \mu \mathrm{g} / \mathrm{ml}$ (PPM).

\section{Preparation of standard solution}

Pipette out $1 \mathrm{ml}$ from standard stock solution and diluted up to $100 \mathrm{ml}$ with analytical grade water to get a concentration of $10 \mu \mathrm{g} / \mathrm{ml}(\mathrm{PPM})$.

\section{B. Preparation of working concentration}

\section{Preparation of standard stock solution}

Standard stock was prepared by dissolving $100 \mathrm{mg}$ of lamivudine in 100 $\mathrm{ml}$ of analytical grade water to get a concentration of $1000 \mu \mathrm{g} / \mathrm{ml}$ (PPM).

\section{Preparation of standard solution}

Pipette out $1 \mathrm{ml}$ from standard stock solution and diluted up to $100 \mathrm{ml}$ with analytical grade water to get a concentration of $10 \mu \mathrm{g} / \mathrm{ml}$ (PPM).

\section{Procedure for UV reading}

Blank Solution: (For Auto zero)
Fill the cuvette with analytical grade water. Wipe it with tissue paper properly then placed inside the chamber. Note down the reading.

\section{Standard Solution}

Fill the cuvette with standard solution. Wipe it with tissue paper properly then placed inside the chamber. Note down the reading.

\section{Sample Solution}

Fill the cuvette with the sample solution. Wipe it with tissue paper properly then placed inside the chamber. Note down the reading.

\section{Procedure for sample preparations}

For analysis of commercial formulations; twenty tablets are taken weighed it and powdered. The powder equivalent to $100 \mathrm{mg}$ of lamivudine was accurately weighed and transferred into the $100 \mathrm{ml}$ of volumetric flask, added $60 \mathrm{ml}$ analytical grade water, the solution was sonicated for $20 \mathrm{~min}$. After sonication cool the flask and diluted up to $100 \mathrm{ml}$ with analytical grade water. Filtered the solution through whatmann filter paper. Pipette out $1 \mathrm{ml}$ of the above solution and diluted up to $100 \mathrm{ml}$ with analytical grade water. The absorbance was measured at $268 \mathrm{~nm}$ [17-21]. The absorbance was recorded:

Table 1: Absorbance of dosage form

\begin{tabular}{lll}
\hline \multicolumn{2}{l}{ Cipla pharmaceutical limited (100 $\mathbf{~ m g})$} & Absorbance \\
\hline S. No. & Sample & 0.0001 \\
\hline 1 & Blank & 0.6209 \\
2 & Standard & 0.6207 \\
\hline
\end{tabular}

Table 2: Dosage form specifications

\begin{tabular}{llllll}
\hline Type & Company & M. D. & E. D. & Batch No. & Average weight (g) \\
\hline 1 & Cipla Pharma LTD $(100 \mathrm{mg})$ & $05 / 2016$ & $07 / 2019$ & GPH 02145 & 0.2027 \\
\hline
\end{tabular}

\section{E. Method of validation}

The proposed method was developed by using linearity, accuracy, precision and ruggedness as per ICH guidelines, 1996.

\section{Linearity}

The linearity of the proposed assay was studied in the concentration range 6-14 PPM at $268 \mathrm{~nm}$. The calibration data showed a linear relationship between concentrations.

\section{Accuracy}

To ensure the accuracy of the method, recovery study was performed by preparing 3 sample solutions of 80,100 and $120 \%$ of working concentration and adding a known amount of active drug to each sample solution and dissolved in $100 \mathrm{ml}$ of the volumetric flask with analytical grade water and measuring the absorbance at $268 \mathrm{~nm}$.

\section{Precision}

The precision of the method was demonstrated by inter-day and intra-day variation studies. Five sample solutions were made and the $\%$ RSD was calculated.

\section{Ruggedness}

Ruggedness is a measure of the reproducibility of a test result under normal, expected operating condition from instrument to instrument and from analyst to analyst. 
Table 3: Linearity studies

\begin{tabular}{lll}
\hline S. No. & Sample concentration & Absorbance \\
\hline 1 & 6 PPM & 0.3867 \\
2 & 8 PPM & 0.5198 \\
3 & 10 PPM & 0.6295 \\
4 & 12 PPM & 0.7392 \\
5 & 14 PPM & 0.864 \\
Correlation coefficient & & 0.998 \\
\hline
\end{tabular}

Table 4: Accuracy studies

\begin{tabular}{llll}
\hline Accuracy (\%) & Qty weighed (mg) & Qty found (mg) & Recovery (98-102\%) \\
\hline 80 & 0.8 & 0.81 & 100.92 \\
100 & 1 & 1.02 & 101.86 \\
120 & 1.2 & 1.18 & 98.55 \\
\hline
\end{tabular}

Table 5: Precision studies

\begin{tabular}{lll}
\hline S. No. & Sample solution & Absorbance \\
\hline 1 & Sample Solution 1 & 0.6206 \\
2 & Sample Solution 2 & 0.6207 \\
3 & Sample Solution 3 & 0.6208 \\
4 & Sample Solution 4 & 0.6205 \\
5 & Sample Solution 5 & 0.6209 \\
MEAN & & 0.6207 \\
SD & & 0.0002 \\
\%SD & & 0.0255 \\
\hline
\end{tabular}

Table 6: Results for ruggedness studies

\begin{tabular}{|c|c|c|c|c|c|}
\hline S. No. & Analyst & Results & Mean & \% assay & \% RSD \\
\hline \multirow[t]{2}{*}{1} & Analyst 1 & 0.6210 & 0.6213 & 100.08 & 0.2821 \\
\hline & & 0.6215 & & & \\
\hline \multirow[t]{2}{*}{2} & Analyst 2 & 0.6207 & 0.6210 & 100.48 & \\
\hline & & 0.6212 & & & \\
\hline
\end{tabular}

Table 7: Results for solubility studies

\begin{tabular}{lll}
\hline S. No. & Title & Result \\
\hline 1 & Analytical grade water & Soluble \\
2 & Methanol & Slightly soluble \\
3 & Acetone & Practically insoluble \\
\hline
\end{tabular}

\section{RESULTS}

Solubility of lamivudine

Solubility test was passed as per criteria.

\section{Melting point of lamivudine}

The melting point of lamivudine was found to be $160-161^{\circ} \mathrm{C}$ (uncorrected).

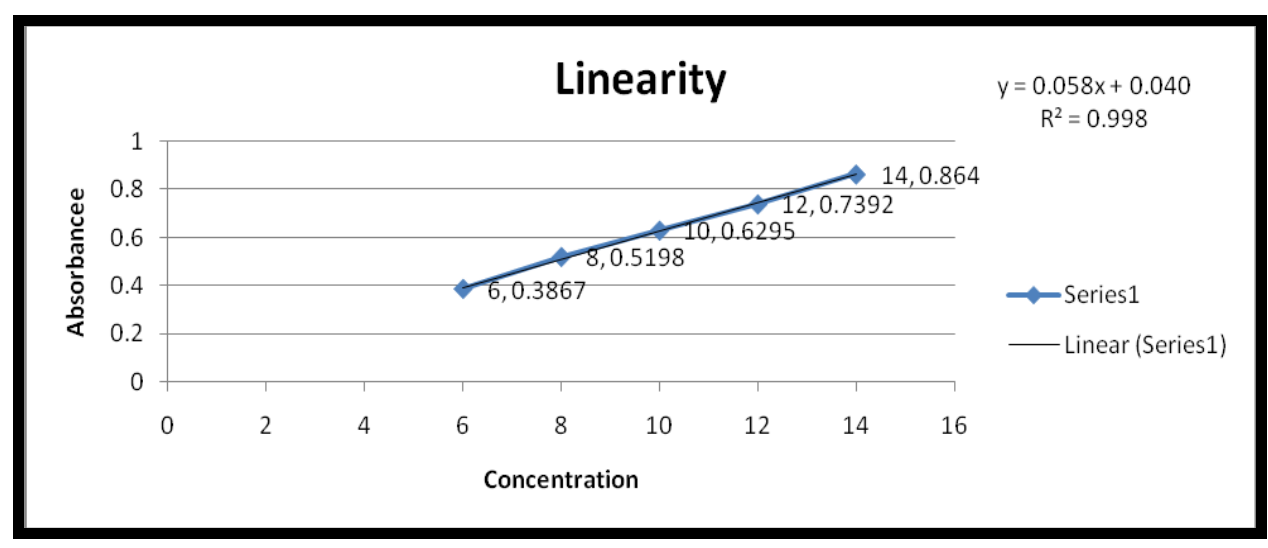

Fig. 3: Lamivudine standard curve 


\section{Results for linearity for assay method of lamivudine}

The linearity of method was determined at concentration level ranging from 6 to $14 \mu \mathrm{g} / \mathrm{ml}$ (PPM). The correlation coefficient value was found to be $\left(R^{2}\right) 0.998$.

\section{Results for accuracy for assay method of lamivudine}

The accuracy of the method was determined by recovery experiments. The recovery studies were carried out and the percentage recovery were calculated and represented in table- 4 . The high percentage of recovery indicates that the proposed method is highly accurate. Accuracy results were found within acceptance criteria that are within $98-102 \%$.

\section{Results for precision for assay method of lamivudine}

The \% RSD for different sample of precision was found to be 0.0255 and it is within acceptance criteria represented in table 5 .

\section{Results for ruggedness for assay method of lamivudine}

The \%RSD for different sample of ruggedness was found to be 0.2329 and it is within acceptance criteria represented in table 6 .

\section{CONCLUSION}

A method for the estimation of lamivudine in tablet form has been developed. From the spectrum of Lamivudine, it was found that the maximum absorbance was $268 \mathrm{~nm}$ in analytical grade water. A good linear relationship was observed in the concentration range of 6-14 $\mu \mathrm{g} / \mathrm{ml}$ (PPM). The high percentage recovery indicates high accuracy of the method. This demonstrates that the developed spectroscopic method is simple, linear, accurate, rugged and precise for the estimation of lamivudine in solid dosage forms. Hence, the method could be considered for the determination of lamivudine in quality control laboratories.

\section{ABBREVARTION}

PPM-Parts per Million, nm-Nanometer, HPLC-High Performance Liquid Chromatography, UV-Ultra violet, HBV-Hepatitis B virus, DNA-Deoxyribonucleic acid, HIV-Human Immunodeficiency Virus, ICH-International Council for Harmonization, RSD-Relative Standard Deviation, SD-Standard Deviation, Qty-Quantity, C-Celsius, M. D.Manufacturing Date, E. D.-Expiry Date

\section{CONFLICT OF INTERESTS}

Declared none

\section{REFERENCES}

1. https://en.wikepedia.org/wiki/lamivudine. [Last accessed on 26 Aug 2017]

2. https://www.drugbank.ca/drugs/DB00709. [Last accessed on 26 Aug 2017]

3. Tripahti KD. Essential of medical pharmacology. $6^{\text {th }}$ Edn. Jaypee Brother Medical publisher, New Delhi; 2003. p. 809-11, 815, 816.

4. Satoskar RS, Rage NN. Pharmacology and pharmacotherapeutics. $23^{\text {rd }}$ Edn. Popular Prakashan, Mumbai; 2013. p. 818.
5. Rang HB, Dale MM, Rither JM. Pharmacology. 4th Edition: Churchill Livingstone; 1999. p. 725-31.

6. SK Berar. Essentials of pharmaceutics. $6^{\text {th }}$ edn. Chand and Company Ltd, New Delhi; 2000. p. 458-9.

7. Nachname, Vorname. Derivative-differential UV spectrophotometry and compensation technique for the simultaneous determination of zidovudine and lamivudine in human serum. Die Pharmazie Int J Pharm Sci 2004;59:106-11.

8. Savaşer A. Determination of abacavir, lamivudine and zidovudine in pharmaceutical tablets, human serum and in drug dissolution studies by HPLC. Chromatographia 2007;65:259-65.

9. Jayaseelan S. A new analytical method development and validation for the simultaneous estimation of lamivudine and stavudine in tablet dosage form by RP-HPLC method. Int J Pharm Tech Res 2010;2:1539-42.

10. Manikanta Kumar A, B Naga, Abstract Sandhya, Mahesh Nasare, VVLN Prasad, Prakash V Diwan. Development and validation of UV spectrophotometric method for simultaneous estimation of lamivudine and efavirenz in the pharmaceutical dosage form. J Adv Pharm Education Res 2012;2:210-4.

11. Nevens, Frederik. Lamivudine therapy for chronic hepatitis B: a six-month randomized dose-ranging study. Gastroenterology 1997;113:1258-63.

12. PV Rajesh, CP Karunasree, G Dharmamoorthy, K Padmini, $\mathrm{CH}$ Sudeer. Development and partial validation of the lamivudine drug in bulk and solid dosage form by uv spectroscopy. IJPDT 2012;2:15-9.

13. Steinmüller, Thomas. Increasing applicability of liver transplantation for patients with hepatitis B-related liver disease. Hepatology 2002;35:1528-35.

14. ICH draft Guidelines on Validation of Analytical Procedures: Definitions and Terminology, Federal Register, 60, IFPMA, Switzerland; 1995. p. 1260.

15. Becket AH, Stenlak JB. Practical pharmaceutical chemistry. $4^{\text {th }}$ Edn. CBS Publisher and Distribution, New Delhi; 2004. p. 275-337.

16. Mendham J, Denney RC. Vogel's Textbook of Quantative Chemical Analysis. th $^{\text {th }}$ Edn. Dorling Kindersley Pvt. Ltd New Delhi; 2006. p. 704-15.

17. Willard H Hobart, Merritt L. Lynne; Instrumental method of analysis. 1st edn CBS Publishers and Distribution, New Delhi; 1986. p. 164-84.

18. Lahane SB, Deokate UA. Development and validated UV spectrophotometric method for estimation of Albendazole in tablet dosage form. WJPR 2014;3:1461-7.

19. British Pharmacopoeia. Vol. I. Published by the stationary office on behalf of the Medicine and Healthcare Products Regulatory Agencies, London; 2008. p. 76-7.

20. United States Pharmacopoeia. In Validation of Compendial Methods. 26th edn: Pharmacopoeial Convention Inc., Rockville; 2003. p. 2439-42.

21. Indian Pharmacopoeia. Vol. II. Ministry of Health and Family Welfare Government of India: Published by Indian Pharmacopoeia Commission, Ghaziabad; 2007. p. 692-3. 